\title{
LAND OG FOLK og AKTUELT's dækning af de vilde strejker
}

I det følgende gengives analyser af LAND OG FOLKs og AKTUELTs behandling af de vilde strejker. Disse to aviser er udvalgt som analyseobjekt, dels fordi de begge postulerer at skrive i lønarbejderens interesser, og dels fordi de læses af mange arbejdere. Mange af de forhold, der fremdrages, er karakteristisk for pressen i det hele taget; man genfinder mange af myterne og forklaringsmekanismerne i andre aviser, som partipolitisk er placeret andet steds. 
Hvad kan en sådan kritisk behandling af aviser vise? Meget ved man jo nok i forvejen, f.eks. at AKTUELT er et socialdemokratisk blad, og at alle aviser modarbejder lønarbejderens interesser, som de er kommet til udtryk i de vilde strejker. Men det må være af værdi at se, hvordan de har gjort det. En ting er at gennemskue avisernes politiske linie og filtrere stoffet derud fra. En anden ting er at gennemskue de mange myter, der kommer frem i bisætningerne, og som oftest bare glider ned. For ikke at tale om en vurdering af stofudvælgelsen; det er jo ikke altid, man har givet sig tid og lejlighed til at opsøge alternative nyhedskilder.

Vi forsøger i analyserne at finde frem til de mekanismer, som styrer avisernes udvælgelse, tolkning og konklusioner på begivenhederne. Altså ideologikritik. Ved ideologi forstår vi noget i retning af »en totalopfattelse af verden ud fra en partikulær bevidsthed«. Man skaber mening med tingene ved at skabe sammenhæng mellem dem, ved at passe dem ind i et mønster. Dette mønster eksisterer ikke nødvendigvis i forvejen, og det ligger ikke i de enkelte fænomener. Derfor kan omverdenen ikke beskrives uden et bestemt udgangspunkt, som indeholder bestemte værdimæssige for- udsætninger og som refererer til en bestemt historisk udvikling.

Ofte skabes denne sammenhæng blot ved hjælp af mytiske forestillinger. Ligesom "primitive« samfund ordner tilværelsen ved at opfinde »tordenguder", oprindelseshistorier, o.s.v., eksisterer der i dag et hav af myter. F.eks. forklares studenteroprøret ved at danne en myte om »studenter, der er uvaskede, dovne, svinske, aktivister o.s.v., som blot laver uro for uroens egen skyld«. En myte er en almindeligt anerkendt forestilling om visse sagsforhold.

Vi må understrege, at vi ikke postulerer noget om avisernes »bevidste« eller »ubevidste« fordrejning eller myteopbygning. Om de gør det bevidst eller ej, er umuligt at påvise og vil desuden være mindre interessant. Endvidere må det understreges, at vi i analysen ikke postulerer nogen værdifrihed. Vi har selvfølgelig en opfattelse af begivenhedernes sammenhæng og historiske baggrund, og den kommer til udtryk i vores analyser. Vi betragter strejkerne som et led i klassekampen; tillidsmandssagen som en styring af begivenhederne for at kunne føre situationen tilbage til status quo. Vi henviser til de øvrige artikler i KURASJE for yderligere klargøring af vores arbejdsmæssige baggrund.

\title{
LAND OG FOLK's behandling af strejkebevægelsen i jannuar - februar 1970
}

\author{
Lisbeth Brinch, Hans Christian Fink, Finn Jørgensen, Dorrit Schmidt
}

Karrikaturtegningens funktion er at karrikere virkeligheden. I karrikaturen ligger der en kritik af virkeligheden. I samme udstrækning som virkeligheden karrikeres, træder præmisserne for kritikken af virkeligheden frem. I DKP's organ LAND OG FOLK bliver karrikaturtegningens funktion udover virkelighedsforvrængningen at forstærke og tydeliggøre de tendenser og holdninger, der udtrykkes i den øvrige del af bladet. Hvor politiske argumenter i reportager og ledere tilslører ideologien, fremtræder den rent og uforfalsket i karrikaturen: klassekampen er en kamp mellem de gode og de onde, en kamp mellem de ærlige, de stærke og solidariske arbejdere og de pengegridske og ubarmhjertige udbyttere.

Marx beskriver kapitalen som dødt arbejde, der kun på vampyragtig vis liver op ved at suge levende arbejde til sig og lever så meget des bedre, som den suger til sig deraf.

I LAND OG FOLK er storkapitalen blevet personificeret som vampyr: »storkapitalens blodtørstige rovdyr «, der kun til en vis grad formår at bevare den demokratiske maske. Hvor den hos Marx er en abstrakt kategori, er den hos LAND OG FOLK konkret fikseret i men- 


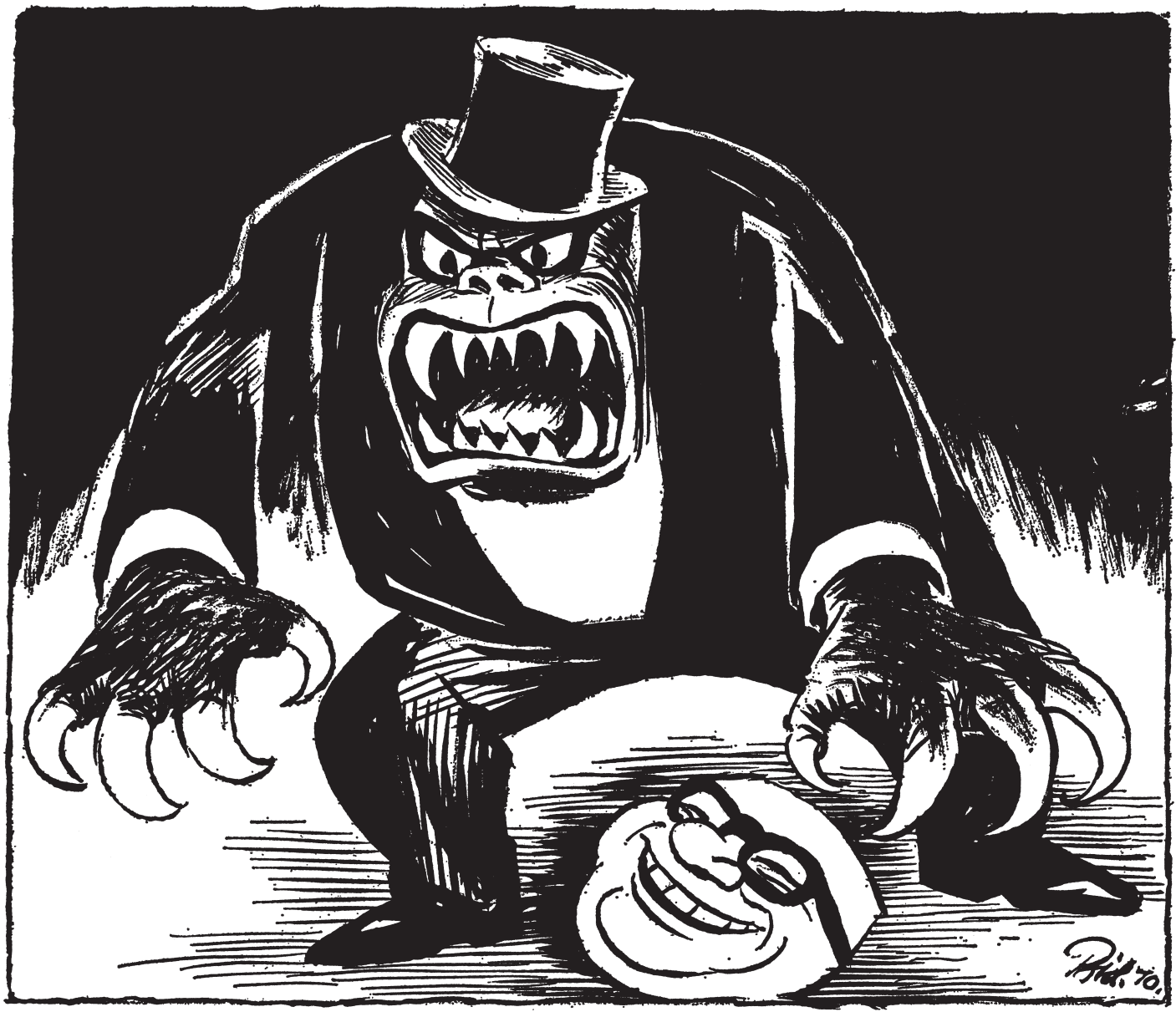

Skibsværftsledelserne kræver tillidsmændene afsat og arbejderne, som strejkede, idømt endnu større bøder end Arbejds-u-retten sædvanligvis idømmer arbejderne.

Få dage før fastelavn var det blodtørstige rovdyr så uheldig at tabe sin gemytlige, demokratiske maske.

neskelige egenskaber, dvs. at den er blevet psykologiseret.

Men hermed forsvinder samtidig forestillingen om den kapitalistiske samfundsformation som et forhold, der ved den ene pol har kapital og ved den anden pol lønarbejde. At såvel kapital som lønarbejde behøver bærere i form af kapitalister og lønarbejdere bliver i LAND OG FOLKs psykologiserende begrebsopfattelse til, at kapitalisten bærer rundt på kapitalen i form af en sæk penge.

Med denne forskydning af betydningen af ordet »bære« er kapitalisten ikke længere underlagt de lovmæssigheder, der styrer kapitalens vækst. Profittens størrelse er et spørgsmål om god eller ond vilje. Det er i denne sammenhæng man skal se kronekravet. Så længe man udøver pression mod den menneskelige vilje i stedet for mod økonomiske lovmæssigheder, er kronekravet realistisk. Kronekravet er den konkrete klassekamp for LAND OG FOLK.

LAND OG FOLKs perspektivindsnævring af klassekampen sker allerede med etableringen af klassekampens forudsætning: kampen mellem lysets og mørkets kræfter. Hermed forklares også, hvorfor man ingen steder i LAND OG FOLK ser bebrejdelser af arbejdere, der er for revolutionære, eller som eskalerer klassekampen for kraftigt, for klassekampen er først 
Tegning fra den 1-2/3-70

Kapitalist i kranforerknibe

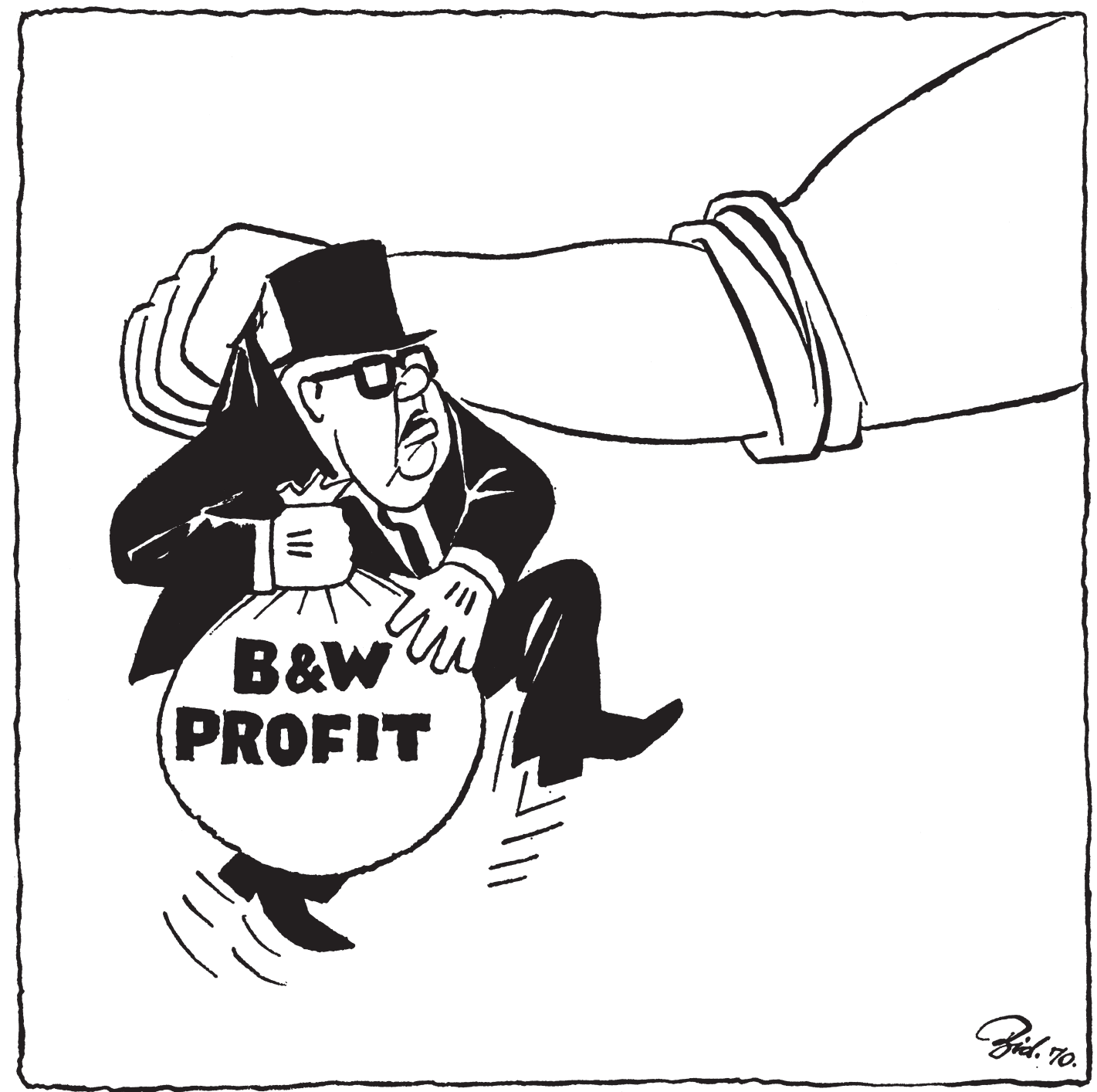

»Der er ingen tvivl om, hvem der er den stærkeste, når de konfronteres direkte med hinanden, arbejder og arbejdsgiver. Det er arbejdsgiveren.« (Aktuelt den 27. februar 1970)

Direktøren: - Hjælp! Min eksistens er truet! Læs hellere i Aktuelt, at jeg er den stærkeste!

rigtig klassekamp fra det øjeblik, den er organiseret. De »vilde« strejker er vilde i LAND OG FOLKs begrebsopfattelse. Det betyder, at de »vilde« strejker i LAND OG FOLK repræsenterer et fosteragtigt stadium i strejkebevægelsen; de er spark i bughulen. Derfor er LAND OG FOLK ikke for sent ude, men kan lige akkurat nå at træde til som fødselshjælper, når man den 6/2-70 skriver:

»Vejen fremad i lønkampen og for at overvinde den forbrugsbegrænsende politik er, at alle kræfter i arbejderbevægelsen opfordrer arbejdspladserne til at sætte ind med politiske aktiviteter og alle tjenlige aktionsmidler.« 


\section{Snebolden ruller}

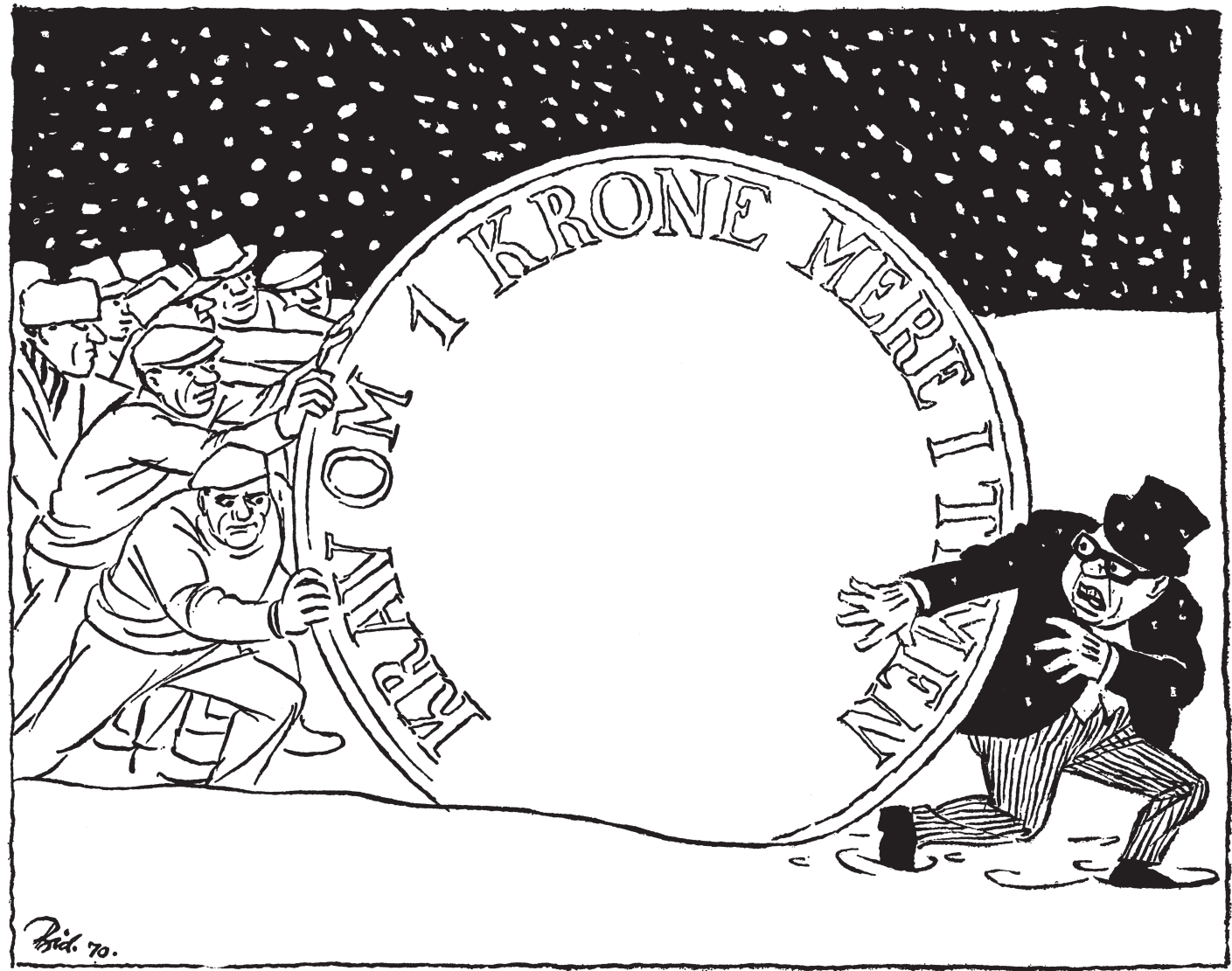

De 38 københavnske fagforeningsformænds og fællestillidsmænds opfordring til at rejse krav om en krone mere i timen får stadig større tilslutning.

Man bemærker her, at det er »arbejderbevægelsen«, der skal sætte bevægelse i »arbejdspladserne«. Arbejderbevægelsen er det faglige bureaukrati.

Ligesom kapitalen i LAND OG FOLKs fremstilling ikke længere er underlagt lovmæssighederne for kapitalens vækst, således er heller ikke fagforeningerne underlagt den kapitalistiske samfundsformations lovmæssigheder. Der eksisterer ikke nogen strukturel organisatorisk krise. Arbejderklassen er ikke en seriestruktur, en atomiseret masse, men en organiseret solidarisk gruppe; derfor er eventuelle bureaukratiseringstendenser ikke i modstrid med arbejdernes interesser, idet det ikke er muligt at manipulere en organiseret gruppe.

De objektive strukturer i fagbevægelsen og overenskomstsystemet er ikke determinerende for tillidsmændenes udfoldelsesmuligheder. Også her er det et spørgsmål om onde eller gode intentioner. Det kan stadig nytte noget at vælge "gode« tillidsmænd og »gode« fagforeningsledere.

I LAND OG FOLKs samfundsbillede eksisterer den korporative stat ikke. Regeringen er enten arbejdernes regering eller arbejdsgivernes regering, som frit og uafhængigt kan lægge sin politik. Kun i denne sammenhæng bliver parolen »arbejderflertal, men med kommunister « forståelig.

Den ideologi, der her er skitseret, vil i det følgende blive uddybet nærmere på grundlag af LAND OG FOLKs behandling af den omtalte strejkeperiode.

\section{Legitimering af kronekravet}

Som nævnt andetsteds i KURASJE er det DKP, der gør den væsentligste indsats for at få 
drejet strejkerne bort fra det »vilde« over i det regelstyrede, kontrollerbare forløb, som kronekravet er udtryk for. Derfor afspejler DKP's organ LAND OG FOLK i høj grad argumentationen for dette.

Denne argumentation går først og fremmest ud på at overbevise om, at den borgerlige regerings økonomiske politik og prisstigningerne har undergravet grundlaget for de indgåede overenskomster, og at kravet om en krone mere i timen er et retfærdigt og rimeligt krav.

Formanden for DMSF afd. 13 citeres den 6/1-70 for følgende:

»Siden vi i marts indgik overenskomst har arbejdsgivernes regering væltet større og større byrder over på lønmodtagerne. Alene kildeskattens høje udskrivningsprocent er bevis nok for, at man bevidst forsøger at forringe lønmodtagernes økonomi. Millioner af kroner flyttes over statsbudgettet fra lønmodtagerne til arbejdsgiverne i form af tilskud, uddannelse og afskrivninger.«

Århussmedenes forbundsformand udtaler:

»Nok så mange statistikker, der søger at fremstille, at der er tale om en reallønsfremgang, kommer til kort over for det praktiske liv. Mon vore kolleger ude omkring i landet, der ligger op til $5 \mathrm{kr}$. under, hvad kolleger her i København tjener i timen, kan se nogen reallønsforbedring.«

(Sidstnævnte argumenterer her nærmere for, at det er regeringens økonomiske politik, der har skylden.)

Men arbejdsgiverne reagerer »kynisk og arrogant « overfor kravene om forhandling fra de enkelte forbund.

I omtalen af sømændenes demonstration og besættelse af Rederiforeningens kontor den 6/1-70 siges:

"At rederierne har råd til en bedre aflønning ses på det millionoverskud aktionærerne hvert år noterer sig.«

Samfundet har altså råd til, at der sker en omfordeling til fordel for arbejderne, idet profitterne er så skyhøje, at de sagtens kan beskæres uden, at det vil true landets interesser udadtil (f.eks. eksporten). Samfundet betragtes som værende tvedelt mellem en overklasse, som består af arbejdsgivere og spekulanter, og en underklasse, som hovedsageligt består af manuelt arbejdende. Klassekampen anses for i den nuværende situation (jan-feb. 1970) at være stærkt skærpet. Denne kamp foregår mest passende mellem arbejdernes og arbejdsgivernes interesseorganisationer, dels på de enkelte arbejdspladser, men helst på det allerhøjeste niveau, mellem LO og Dansk Arbejdsgiverforening.
LAND OG FOLKs iver for at dreje uroen på arbejdspladsen bort fra det »vilde« og over i det kontrollerbare kronekrav, viser sig dels i mængden af artikler om emnet og dermed i den interesse, man tillægger arbejdsnedlæggelser rundt omkring på landets arbejdspladser, og dels i hvordan selve forløbet i disse reportager fra uroens arnested former sig.

Man indleder som regel med en kort beskrivelse af de dårlige arbejdsforhold på stedet, den dårlige trivsel, som arbejdsgiverne gennem deres ret til at lede og fordele arbejdet er skyld $i$. Hvis der kommer en udtalelse fra en person på stedet, er det altid fra en tillidsmand eller en fagforeningsmand, men aldrig fra en "menig" arbejder. Derefter bevæger man sig lynhurtigt over i lønspørgsmål, sammenligner lønnen på stedet med andre steder i landet og med den minimalløn, arbejderne krævede ved overenskomsternes indgåelse, men aldrig opnåede.

Konklusionen bliver så: Arbejderne må stå sammen og kræve lønindrømmelser fra arbejdsgiverne og ændring af regeringens økonomiske politik. Endelig en opfordring til at slutte op om kronekravet eller en påvisning af, hvor godt det går.

\section{Legitimering aftillidsmands- institutionen}

Arbejdernes repræsentanter (fagforeningsformænd og især tillidsmænd) fremstilles i LAND OG FOLK som deres "sande« repræsentanter, der bevidst arbejder for at skaffe arbejderne bedre kår. Når LAND OG FOLK i spørgsmålet om arbejdernes repræsentanter kan undgå den nærliggende konfrontation med pamperbegrebet og manipulationsfænomenet, så ligger det (som nævnt i indledningen) i deres opfattelse af arbejderklassen som en alt for generelt defineret masse, der er politisk bevidst, organiseret og solidarisk. En solidarisk og bevidst gruppe mennesker er nemlig ikke let at manipulere, og de vil også sørge for at kontrollere deres valgte repræsentanter.

Ifølge LANDOG FOLK har arbejderne, tillidsmændene og organisationerne altså interessefællesskab - på nær med nogle få i LO’s top, men disse uoverensstemmelser med ideologien bliver personaliseret og konkretiseret og således løsrevet fra den sammenhæng, de skulle ses i.

$\mathrm{Nu}$ findes der jo talrige eksempler på, at tillidsmændene har undladt at forsvare arbejdernes interesser, tilfælde hvor de tværtimod har 
gjort alt for at opretholde ro og orden på arbejdspladsen. (Se Den danske Fagforstening). Tillidsmandsinstitutionen er med rette rygraden i dansk fagbevægelse, og samtidig kan det jo ikke nægtes, at den er en vigtig del af rygraden i DKP's selvopholdelsesdrift. (Som bekendt er det DKP's force, at det er lykkedes dem at have kontrol over en del kommunistiske tillidsmænd rundt omkring i landet). LAND OG FOLK er imidlertid godt klar over, at hvis tillidsmændene skal have nogen legitim funktion på arbejdspladsen, må de fremstå som fuldt solidariske og på lige fod med de repræsenterede, og således bliver de også søgt fremstillet i LAND OG FOLK.

I slutningen af januar (den 25.-26./1-70) lige før 24-timers-strejkens planlægning på mødet mellem tillidsmændene fra værfterne er der en stor artikel på forsiden med overskriften:

»Vrftsarbejderne i aktion mod den økonomiske politik«. »Arbejderne på Odense A/S, Odense og Lindø afdelinger søger nu at kontakte bl.a. arbejderne på Danværfterne. . .«. »Efter hvad der oplyses overfor LAND OG FOLK er hensigten, på en stærk og markant måde at understrege over for regeringen, at dens økonomiske politik vil arbejderne ikke fortsat affinde sig med«.

Senere i artiklen viser det sig, at alt initiativ er taget af værfternes tillidsmænd, og at de skjult citerede udtalelser er tillidsmændenes og ikke arbejdernes.

Ligeledes behandler LAND OG FOLK tillidsmandsmødet før 24-timerstrejken som et entydigt bevis på, at tillidsmændene varetager arbejdernes interesser, fremfor at fremstille tillidsmændene som lus mellem to negle, der har visse særlige interesser at forsvare på grund af den specielle stilling, de indtager i organisationshierarkiet. Man kunne forestille sig, at tillidsmændenes aktion ville have en dæmpende og kanaliserende virkning på situationen hos arbejderne, således at konflikterne ville blive ført ind i det rigtige systems rækker igen. En stor 24-timers strejke er jo i virkeligheden ingen pression mod arbejdsgiverne - hverken økonomisk eller psykologisk, men når tillidsmændene offentligt og samlet opfordrer hertil, og når arbejderne ikke har fundet alternative organisationsformer såsom strejkekomiteer og basisgrupper er der ikke meget andet for dem at gøre end at følge trop.

At arbejdsgiverne 3-4 dage efter 24-timersstrejken søger at afsætte tillidsmændene i følge overenskomsternes paragraf 2, optager LAND OG FOLK som et slag mod den demokratiske fagbevægelse og mod arbejderklassens aktionsmuligheder som sådanne - de betegner arbejdsgiverne som "provokatører« og »vilde urostiftere « uden overhovedet at nævne, at arbejdsgiverne ville kunne finde lovhjemmel for deres aktion i overenskomstaftalerne. Således opfordrer LAND OG FOLK til aktion for at beholde de forfulgte tillidsmænd og ikke til aktion for at ændre overenskomstsystemet.

Samtidig understreger de arbejdernes solidaritet med tillidsmændene. Lederoverskrift: »En for alle og alle for en«.

»I dag skal centralorganisationern have forhandlinger med 'jernets' arbejdsgivere om konflikten vedrørende de 26 værftstillidsmænd. I denne forhandling skal alle værfters fællestillidsmænd deltage. På alle værfterne er arbejderne gået $\mathrm{i}$ arbejde for at understrege deres vilje til at nå et positivt resultat i den konflikt værftsledelserne, inspireret af jernbaronerne har sat i værk på de danske skibsværfter.«

\section{LAND OG FOLKog arbejdsretten}

Ligesom arbejdsgivernes udspil mod tillidsmændene fremstilles som et isoleret fænomen, bliver arbejdsretten og dennes funktion behandlet for sig selv, og dens naturlige sammenhæng med resten af overenskomstsystemet tilsløres. Arbejdsretten bliver først rigtigt et mål for kritik i LAND OG FOLK efter at bøderne bliver forhøjet den 11/2-70. Kritikken går klart på arbejdsretten selv. men dennes stilling indenfor det fagretslige system bliver ikke undersøgt. Den kaldes for en klassedomstol, men hvorfor den fungerer sådan på trods af dens »demokratiske« opbygning med tre repræsentanter fra hver organisation og en uvildig dommer forklares ikke. Det, der bl.a. kunne ske ved en sådan undersøgelse, var, at der måske blev rokket ved det repræsentative systems legitimitet, og derved ville LAND OG FOLKs ideologi få et ordentligt skud for boven.

Kommentarerne af gårsdagens begivenheder i arbejdsretten berettes i LAND OG FOLK den 12/2-70 på følgende måde:

»Knus arbejdsrettens tyranni! Arbejdsretten har fuldt og helt imødekommet arbejdsgivernes krav om forhøjede bøder til de arbejdere, der kæmper for deres ret. Arbejdsretten har igen fastslået, at den alene er et redskab for arbejdsgiverne, en klassedomstol til at håndhæve arbejdsgivernes enevælde på arbejdspladserne og erklære enhver strejke 'ulovlig' [. . . ] LO's repræsen- 
tanter i arbejdsretten har ikke godkendt straffene. Det kunne også bare mangle. En af LO's dommere har fulgt arbejdspladsernes opfordring til at nedlægge sit hverv i arbejdsretten og kræve denne klassedomstol afskaffet.«

Karakteristisk er det, at for DKP og LAND OG FOLK kulminerer aktionerne mod klasse- domstolen med Hanne Reintofts forslag i Folketinget om ophævelse af denne. Vi vil ikke her gå nærmere ind på LAND OG FOLK og parlamentet, og LAND OG FOLK og den korporative stat, men henvise til artiklen: Revolution og Kontrarevolution i Danmark

\title{
AKTUELT's behandling af de vilde strejker
}

\author{
Gert Gronemann og Inger Stauning
}

AKTUELTs syn på strejkerne kommer med al ønskelig tydelighed til udtryk i overskrifterne. Man kan betragte en strejke fra to synsvinkler: fra arbejdernes og fra arbejdsgivernes. Fra arbejdernes synsvinkel er den en protest mod visse misforhold, og fra arbejdsgiverens er den en forsinkelse af produktionen. Det er bemærkelsesværdigt, at de fleste overskrifter lægger vægt på produktionens forsinkelse. (»Ingen kød hos IRMA«, »Forsinkelser i nat på AKTUELT«, »Strejken mærkedes kun som en snert«, »De fleste værfter atter lamme«t). Kun tre overskrifter medtager årsagen til strejkerne.

Man kunne synes, at en tredie mulighed var at beskrive strejkerne blot konstaterende deres "materielle« aspekt. Man fortæller hvad der faktisk er sket, hvordan strejken er forløbet, hvordan den øjeblikkelige situation er. Dette gøres enten ved tal (»18.000 på 9 værfter vil strejke fra mandag kl. 6«) eller ved metaforisk (ved hjælp af billeder) at beskrive tilstanden: (»Situationen på B\&W afdæmpet - overophedet andre steder «, »Sindene på værfterne igen på kogepunktet«). Denne reportageform er uhyre almindelig ved studenterdemonstrationer, krigshandlinger o.s.v. og bevirker, at begivenhederne blottes totalt for mening. Derfor er denne form for reportage også imod arbejdernes interesser. Den skjuler årsagerne til strejkerne, ja, at der overhovedet $e r$ nogen årsager.

Forståelsen for begivenhederne, meningen med dem, får man gennem forskelligt baggrundsstof. Man kunne tænke sig referater af forskellige personers synspunkter, interviews med involverede, historisk baggrund, forskellige synsvinkler på begivenhederne, skildringer af forholdene på enkelte virksomheder o.s.v. Men i AKTUELTs baggrundsartikler kommer kun LO-meninger til udtryk. Særlig rigt er Thomas Nielsen og Hans Rasmussen repræsenteret og i mindre grad Anker Jørgensen og Holger Nielsen. Desuden er der en del »anonyme« udtalelser fra forskellige fagforbund (hovedbestyrelser og forretningsudvalg).

I lederne kommer avisens holdning til begivenhederne til udtryk, forklaringer, der går ud på, hvorfor de benyttede metoder er forfejlede, hvad der bør gøres i stedet, og hvad der vil ske, hvis man fremturer i den nuværende dårskab. I artiklerne fremhæves det, der er særlig fordelagtigt for LO-SD synspunkterne, begejstrede udtalelser om Folketingets 21-mandsudvalg (hvis idé var dødfødt fra starten), omtale af fagforbundsinitiativer og af aktiviteterne i forbindelse med Folketinget. Baggrundsstoffet omhandler fortolkninger af og grunde til begivenhederne samt recepter på, hvordan konflikterne skal løses; alt holdt inden for rammerne af LO-SD's ideer og problemstillinger, enten ved at gå ud fra disse, eller ved at lade LO-SD-folk selv fremkomme med deres synspunkter.

Ved dette overblik over stoffet om strejker ser man altså, at AKTUELT ganske vist dækker begivenhederne, men allerede i dækningen er negativt indstillet, at AKTUELT ganske vist giver baggrundsorientering, men at den er en ensidig indoktrinering af LO- og SD-synspunkter.

Vi kan nu gå lidt nærmere ind på AKTUELTs tolkning af strejkerne, og se på præmisserne for den. 


\section{AKTUELTs fortolkning af begivenhederne}

AKTUELT tolker strejkerne som udtryk for ønske om lønforbedringer. I overenskomsten er det grundlæggende problem vedrørende lønnen o.s.v. midlertidigt ordnet. Der er på demokratisk vis skabt enighed mellem parterne i modsætningsforholdet. Dette er grundlaget for AKTUELT, udgangspunktet, og det kan der ikke røres ved. Derfor må lønproblemer komme af (1) regeringens udhuling af overenskomsten, (2) utilstrækkelig udnyttelse af overenskomstens muligheder. Man må altså undersøge, om reallønnen vitterligt er faldet; arbejderbevægelsens økonomer har beregnet, at det er den ikke, (Thomas Nielsen, den 6/1-70). Derfor er der ikke basis for generelle lønkrav fra LO's side. (Men i utallige artikler understreges det, at LO vil støtte medlemmerne i deres »overenskomstmæssigt betingede lønkrav« - den 6/1-70, den 7/1-70, etc.). Selv om reallønnen ikke er faldet, er regeringen dog skyld i lønproblemet, idet dens skattepolitik er helt urimelig. Den 17/1-70 giver AKTUELT første gang årsagen til strejkerne:

»Utilfredsheden er resultat af regeringens økonomiske politik, som især har ramt lønmodtagerne, erklærer LO, der opfordrer til øget aktivitet for at fremkalde et regeringsskifte.»

Denne definition af problemet (højere løn) og af årsagerne til problemet (regeringens økonomiske politik, utilstrækkelig udnyttelse af de lovlige muligheder) giver basis for kritik af metoderne. Det politiske skal Socialdemokratiet (SD) nok sørge for, og »politisk har det næppe betydning overhovedet, at en så forholdsvis begrænset kreds blandt arbejderne tager sig en dyrt betalt fridag (leder, den 3/2-70). Og af »den ringe deltagelse« i 24-timersaktionen:

»Kan man drage den lære, at løntillæg i en løbende overenskomstperiode fås kun ved at bruge den lovlige fremgangsmåde, som anvises i overenskomsterne, og som fagbevægelsens ansvarlige leder har henvist til,« (leder den 3/2-70).

I samme leder fortæller AKTUELT, at strejker »er et slag i luften, som nok kan tilkendegive en vis utilfredshed, men som ikke kan give resultater «, og at de »slår skår i noget, som er dyrebart for faglige fremskridt og ændringer i det politiske system «.

AKTUELT kommer altså til det resultat, at strejker er unyttige, ja direkte skadelige. Det kunne være interessant at se lidt på, hvordan dette resultat nås.

\section{Retorikken omkring strejker}

I strejkebeskrivelser bruges ofte vendinger som »situationen afdæmpet/overophedet«, "ro/uro på arbejdsmarkedet«, »stemningen på kogepunktet«, o.s.v. Disse gentagne metaforer giver udtryk for arbejdsmarkedet som en mekanisme, et element, der reagerer ganske uhæmmet, ukontrolleret, efter mystiske love. Samtidig er det underforstået, at det er ønskværdigt at bringe den »normale« tilstand tilbage (overophedet, $u$ ro).

Når man fra beskrivelsen har fået indoktrineret denne (skjulte) synsvinkel, kan man lettere acceptere AKTUELTs påstande om, at strejkerne er resultat af »tilfældige stemninger « (leder den 3/2-70). Og at det er kommunisterne, der står bag og "puster til ilden«.

Det meget brugte tillægsord »ulovlig« antyder, at der er noget »moralsk forkasteligt« ved at strejke (efter følgende skjulte tankegang: Det er moralsk forkasteligt at stjæle, derfor er det ulovligt - det er ulovligt at strejke uvarslet, derfor er det moralsk forkasteligt).

Endvidere er der brugen af ordet »demokrati«. Strejker er »udemokratiske«, derfor bør man ikke tage hensyn til de strejkendes krav. F.eks. er rederibesættelsen ikke i overensstemmelse med "god demokratisk skik «, som sættes lig: ikke at gribe »forstyrrende ind $i$ andre menneskers daglige arbejdsgang«. At gøre dette er »terror «! (leder den 7/1-70). Demokrati er at »medlemmerne først lokalt og senere gennem deres valgte repræsentanter til ledelsen og i sidste instans kongressen får mulighed for at træffe afgørelserne«! (leder den 31/1-70).

Som demokrati-begrebet bruges her, betyder det simpelthen en bestemt valgmetode (med visse mellemrum vælger folket repræsentanter, som vælger repræsentanter, som vælger repræsentanter, som vælger repræsentanter, som vælger repræsentanter, som tager beslutningerne).

Men demokrati har også en anden, positiv betydning, nemlig »folkestyre«. Vi ønsker alle folkets selvbestemmelsesret, enhvers deltagelse i beslutningsprocesserne, enhvers ret til at blive hørt og til, at man tager hensyn til hans meninger, kort sagt »rigtigt« demokrati. En strejke er netop en tilkendegivelse af et antal menneskers meninger - og havde vi »rigtigt« demokrati, 
burde man have lyttet til og imødekommet de strejkendes krav.

Når AKTUELT bruger ordet »udemokratisk «, er det for så vidt rigtigt brugt i denne sammenhæng, idet strejkerne jo er udenomsparlamentariske. Men ordet sættes i ens bevidsthed lig anarki/diktatur, nemlig som modsætning til demokrati + folkestyre.

AKTUELT taler ustandseligt om resultater: de resultater, man opnår ad de lovlige kanaler, men ikke opnår ad ulovlige. Ordet er positivt farvet, men det er dobbelttydigt. På den ene side er det blot det, en handling fører med sig, på den anden side er det kontante forbedringer. Strejkerne har ganske vist ikke medført umiddelbare, kontante forbedringer, men at de gør det på længere sigt, er vist uomtvisteligt. Endvidere manifesterer de en fælles utilfredshed og medvirker derved til en bevidstgørelse både hos de strejkende og hos andre om arbejdernes situation. De resultater, AKTUELT taler om, er enten hypotetiske: "kunne have været opnået ved lovlige midler«, eller det er »5-øresresultater«. »Resultater« er et manaord - ligesom lovlig, demokratisk - der kan lægges til et eller andet og derved give dette et eller andet positiv værdi.

\section{Definition af problem og årsager}

Det er klart, at hvis ønsket kun er straks at få lidt mere i løn, må organisationerne klare det. De er berettigede forhandlingspartnere, og »arbejdsgiverne ønsker ikke at forhandle, så længe der strejkes«. Dertil kommer: da regeringen er årsag, må regeringen skiftes ud.

AKTUELT går helt uden om, at der kan være langt mere dybtgående årsager: at arbejderne er utilfredse med selve deres situation som lønslaver, med grundlaget for overenskomsten, med det arbejdsretslige system, med organisationsformerne, med arbejdsgivernes "ret til at lede og fordele arbejdet«, med regeringen (som lige så godt kunne have være socialdemokratisk): med deres totale afmagt over for hele systemet.

Når AKTUELT i reportager, LO-artikler og ledere konsekvent skjuler disse andre mulige årsager, bliver den ene (nemlig regeringen) årsagen for den menige læser, og AKTUELTs holdning og kritik bliver rimelig og logisk. Afgrænsning af problemet i en given konflikt er et af de bedste midler til manipulation. Det kunne være interessant at undersøge i hvor høj grad, avisernes definition af arbejdernes problemer virker tilbage på arbejdernes egen formulering af problemet.

\section{Modsatningsforhold}

Det er vigtigt $i$ alle problemanalyser at kunne fastslå mellem hvem og hvori modsætningerne består, fordi modsætningerne jo er basis for konflikter. AKTUELT skjuler helt modsætningen ledere - ledede, som findes i alle hierarkiske strukturer, altså også - endda overordentlig udpræget - i arbejderorganisationerne. Men for AKTUELT er LOs interesser lig med arbejdernes interesser; angreb på tillidsmændene er lig med angreb på arbejderne. Men det er arbejderne, der skal integreres i organisationerne, hvilket fremgår af, at en handling fra arbejderside, der går uden om organisationerne - strejker, demonstrationer o.s.v. - er et angreb på organisationerne.

Mere bemærkelsesværdigt er det, at modsætningen arbejder - arbejdsgiver efterhånden køres over i en modsætning mellem på den ene side arbejderne, arbejdsgiverne, LO og Socialdemokratiet og på den anden side kommunisterne og den borgerlige regering. Det lyder jo fantastisk!

I en artikel den 7/2-70 fortæller Thomas Nielsen, at den borgerlige regering er årsag til utilfredsheden, at kommunisterne (sic) er årsag til den borgerlige regering, at kommunisterne udnytter utilfredsheden til at skabe uro, at uro blot medfører tabt arbejdsfortjeneste for arbejderne, og at den i sit inderste er vendt mod organisationerne (= arbejderne). Dette synspunkt er ifølge lederne også AKTUELTs.

At LO og arbejderne har samme interesse forudsættes. Og Socialdemokratiet støtter arbejderne ved at forsøge at mildne regeringens økonomiske politik. Desuden er det jo traditionelt arbejdernes parti. Men arbejdere og arbejdsgivere har fælles interesser:

»Alle - både arbejdere og arbejdsgivere - har en interesse i, at der nu skabes normale tilstande på arbejdsmarkedet, «(leder den 11/3-70),

Især har de fælles interesser mod regeringen, fordi regeringen er skyld i uroen, og uroen medfører tab for arbejdsgiverne. Dette tab er til skade for hele det danske samfund (går det erhvervslivet godt, går det os alle godt). I en stort opsat artikel hedder det: 
»Ro på arbejdsmarkedet er meget mere værd end regeringens krav om millardoverskud, « det vil sige mere værd for landets økonomi, altså for befolkningen, altså også for arbejderne. Her tages de »ulovlige« strejker til indtægt for AKTUELTs egne synspunkter.

\section{Organisationsforhold}

AKTUELT anser overenskomsten for en om ikke ideel så tålelig balance mellem arbejdsmarkedets parter. Der er et modsætningsforhold mellem arbejdere og arbejdsgivere; dette er der fundet en løsning på, ved at arbejdernes repræsentanter, LO og Arbejdsgiverforeningen er blevet enige om overenskomsten. Arbejdsretten, bestående af repræsentanter fra begge parter og en »uvildig « formand, sørger for at den overholdes. Hele dette system må der ikke rokkes ved.

Strejker er et angreb på hele systemet, fordi de »ødelægger det gode samarbejdsforhold mellem arbejdere og arbejdsgivere«, og fordi de fornægter organisationerne. Strejker peger $p a$ det grundlæggende modsætningsforhold, der er mellem arbejdere og arbejdsgivere. Dette modsætningsforhold søger organisationerne og arbejdsgiverne ellers at skjule ved at »forhandle«, »samarbejde«, »nå til enighed «, »løse problemer, der står dem imellem«, ved at have tillidsmænd, der »formidler kontakt« o.s.v. Men det er umuligt at nå til anden »enighed « end den arbejdsgiverne forlanger, fordi de har pengene og dermed magten. Det, der betinger modsætningen, er merværdien, som dels er profit for arbejdsgiveren, dels går til investeringer, som kun arbejdsgiveren bestemmer over. Dette modsætningsforhold er det i organisationernes interesse at skjule, fordi det er deres eksistensbetingelse, at det er muligt at bygge bro, at nå til enighed. AKTUELT varetager denne interesse ved at fordømme strejkerne, ved at henvise til »lovlige« »forhand- lings« veje, ved at indskrænke problemkomplekset, ved at tilsløre modsætningerne. Samt ved at holde fast ved det overenskomstmæssige grundlag for enhver pris.

I sagen omkring bodsforhøjelserne siger AKTUELT:

»Uanset at vi finder kendelsen uheldig, så må kritikken først og fremmest rettes mod dem, der har rejst sagen, og ikke mod retten, (leder den 13/3-70). lige!

»Uheldig« - arbejdsgiverne er vel nok tarve-

AKTUELT er ligeledes dybt forarget over arbejdsgivernes henstilling til tillidsmændene om at gå af. I tillidsmandsreglerne står der direkte, at tillidsmændene skal sørge for ro på arbejdspladsen; de har brudt disse reglerved at opfordre til strejke, og arbejdsgivernes brev er således helt korrekt. Dette nævner AKTUELT ikke.

AKTUELT slår to fluer med ét smæk ved at påstå, at årsagen til strejken er regeringens økonomiske politik: både afleder man opmærksomheden fra det »lovlige« grundlag og LO, og man vender den mod Socialdemokratiet som alternativ til den borgerlige regering.

\section{Konklusion}

AKTUELTs holdning til begivenhederne, således som den kommer til udtryk i reportager, artikler og ledere er helt igennem bestemt af, at AKTUELT er LO-blad og socialdemokratisk.

Dets budskaber til arbejderne er: Hold jer til organisationerne! Rok ikke ved overenskomster, arbejdsret, tillidsmandsregler o.s.v.! Ud med den borgerlige regering (og ind med en socialdemokratisk)! Altså: Støt LO og SD og affind jer i øvrigt med jeres totale afmagt! 